\title{
Near infrared as an auxiliary tool for wood identification in sacred art in Brazil
}

\author{
Silvana Nisgoski ${ }^{1 \star}$, Francielle Rodrigues Ribeiro Batista ${ }^{1}$, André Vieira Colombo ${ }^{2}$, Valtencir Almeida dos \\ Passos $^{3}$, Graciela Ines Bolzon de Muñiz ${ }^{1}$
}

\footnotetext{
${ }^{1}$ Programa de Pós-Graduação em Engenharia Florestal (PPGEF), Universidade Federal do Paraná, Curitiba, PR, Brasil.

${ }^{2}$ Atelier de Conservação e Restauração de Bens Culturais LTDA, Juiz de Fora, MG, Brasil.

${ }^{3}$ Programa de Pós-Graduação em Artes, Cultura e Linguagens (PPGACL), Universidade Federal de Juiz de Fora, Juiz de Fora, MG, Brasil.
}

\begin{abstract}
Appropriate conservation and restoration of historical objects in wood must be done based on an accurate identification of species, which can indicate to the restorer the origin of material and some specificity of these objects. Little samples from nine sacred objects came from an atelier in Minas Gerais state, Brazil. Objects were from collections of churches and were in restoration process. Wood identification was based on macro and microscopic characteristics. Infrared analyses were performed in a spectrometer equipped with an integrating sphere and operating in reflectance mode in a spectral range of $4000-10000 \mathrm{~cm}^{-1}$ with resolution of $4 \mathrm{~cm}^{-1}$. Spectra were obtained directly from all surfaces of samples, without identification of section in a number of 20 by object. Six samples from sacred objects were identified, by anatomic characteristics, as from genus Cedrela P. Browne (Meliaceae). Other three samples were from genera Entandrophragma C.DC. (Meliaceae), Plathymenia Benth. (Fabaceae) and Tilia L. (Malvaceae). Principal differences in anatomic characteristics were observed in distinction of growth rings, porosity and axial parenchyma. Near infrared grouped material with similar characteristics to Cedrela sp. and showed the potential to be applied as an auxiliary tool to anatomical characterization in wood sacred objects identification.

Keywords: wooden images; species discrimination; spectroscopy.
\end{abstract}

\section{Introduction}

Archaeological wood can be defined as wood that carries traces of the past cultural or technological activities related to human history, which makes them representative of their historical period or social context and valuable for archaeologists and historians (LUCEJKO et al., 2015). Appropriate conservation of historical architectures in wood as church, sacred images and other objects must be done based on an accurate identification of species applied in wooden objects (HOBRO et al., 2010).

In Brazilian culture, baroque is one of the most representative periods of expression (ANDREACCI; MELO JÚNIOR, 2011). Sculptures from sacred art produced in century XVII were principally made from clay. Otherwise in XVIII wood was the most important material and in Minas
Gerais state, cedar (Cedrela P. Browne - Meliaceae) was the principal species, being verified others from genera Ocotea Aubl. and Nectandra Rol. ex Rottb. (Lauraceae), Cordia L. (Boraginaceae), Guarea F. Allam ex L. (Meliaceae), Araucaria Juss (Araucariaceae), between others (COELHO, 2005).

Conservation and restoration process imply in a previous knowledge of botanic identity and characteristics of wood applied in some objects. These processes are, by nature, a moment of knowledge of work of art, so the botanical identification can indicate to the restorer the origin of material, aspects not always possible to be verified only by the formal and stylistic analysis, given the historical and cultural specificities of the great circulation areas of these objects. Wood anatomy is frequently applied in species identification in sacred art or historical material related to religious (MELO 
JÚNIOR, 2012), for example, for evaluating structure of Cappella Palatina in Palermo - Italy (ROMAGNOLI et al., 2007) and church of Nossa Senhora da Conceição in the city of Matozinhos - Minas Gerais - Brazil (ANDREACCI; MELO JÚNIOR, 2011).

Some disadvantages are that only little or few samples can be obtained because the analysis cannot appreciably modify any part, or change the integrity of the wooden artifact, and also much time wood present degradations in different levels, what can difficult analysis. In some cases, only the botanical family can be correctly identified (GASSON, 2011). The great diversity in flora and natural differences within a species, caused by a complex sequence of interactions between geneprotein expression and the local environment as climate, nutritional factors, growth regulators and physical stresses (DOWNES; DREW, 2008) are other factors that can interfere in accurate wood identification based on little and/or degraded samples.

One alternative can be the use of nondestructive techniques like infrared spectroscopy and information collected directly from material surface, as reported in literature for detecting different properties of lignocellulosic materials (TSUCHIKAWA; KOBORI, 2015). The possible application of Fourier Transform Infrared Spectroscopy (FTIR) in wooden artifacts is described and differences in fingerprints of species are attributed to environment conditions that affect degradations of polysaccharides and lignin (BUOSO et al., 2016; TRAORÉ et al., 2016). On the other hand, Largo-Gosens et al. (2014) presented a review of FTIR applications in studies with cell wall, and commented that it is not usually employed alone to analyze cell walls, but to confirm the results obtained with other chemical methods because the information from spectra is complex and there are overlapping peaks.

The potential of near infrared (NIR) in species identification is present in studies with woods similar to mahogany (BERGO et al., 2016; SOARES et al., 2017), in pine species in Korean architecture (HWANG et al., 2016), with Tsuga heterophylla (Raf). Sarg and Abies amabilis Douglas ex J. Forbes, Pinaceae family (LAZARESCU et al., 2017) and eucalyptus species (NISGOSKI et al., 2017) between others. Sandak et al. (2009) showed the potential of NIR for recognition of wood species, in quantification of chemical composition, detection of surface finish type, monitoring wood weathering and for analyses of archeological wood and determination of its geographical origin. In historical wood, evaluations of chemical composition (SANDAK et al., 2010) and identification of pigments applied in artistic objects (CLOUTIS et al., 2016a,b) reported that NIR spectroscopy is useful in understanding the changes in wood chemistry and its molecular degradation (INAGAKI et al., 2009).

Based on exposed above, the aim of this study is to evaluate the potential of NIR infrared as rapid and first step in wood identification of sacred objects in Brazil, as an auxiliary tool to wood anatomy.

\section{Material and Methods}

\section{Material}

Little samples from nine sacred objects came from an atelier of art and restoration (Figure 1) with some information's of its origin (Table 1). Material were from collections of churches in Minas Gerais state, Brazil, and were in restoration process.

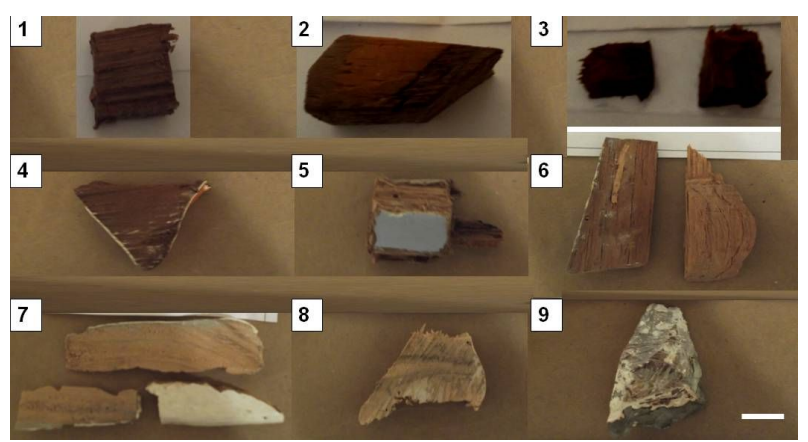

Figure 1. Samples from nine sacred objects from Minas Gerais churches. Scale bar $=1 \mathrm{~cm}$.

Figura 1. Amostras de nove objetos sacros de igrejas de Minas Gerais. Barra $=1 \mathrm{~cm}$. 
Table 1. Name of sacred objects from Minas Gerais churches and its origin. Number is related to Figure 1.

Tabela 1. Nome dos objetos sacros das igrejas de Minas Gerais e sua origem. Número relacionado com Figura 1.

\begin{tabular}{|c|c|c|}
\hline Number & Sacred Images & Origin \\
\hline 1 & Sacrário do Retábulo & Minas Gerais - Brazil \\
\hline 2 & $\begin{array}{l}\text { Oratório de Nossa } \\
\text { Senhora da Piedade }\end{array}$ & Unknown \\
\hline 3 & São Miguel & Portugal \\
\hline 4 & São José de Botas & $\begin{array}{c}\text { Tocantins - MG - } \\
\text { Brazil }\end{array}$ \\
\hline 5 & $\begin{array}{c}\text { Nossa Senhora das } \\
\text { Dores }\end{array}$ & $\begin{array}{c}\text { Tocantins - MG - } \\
\text { Brazil }\end{array}$ \\
\hline 6 & Senhor do Passos & $\begin{array}{c}\text { Tocantins - MG - } \\
\text { Brazil }\end{array}$ \\
\hline 7 & Senhor Morto & $\begin{array}{c}\text { Tocantins - MG - } \\
\text { Brazil }\end{array}$ \\
\hline 8 & $\begin{array}{c}\text { Sagrado Coração de } \\
\text { Jesus }\end{array}$ & $\begin{array}{c}\text { Dores do Turvo - MG } \\
\text { Brazil }\end{array}$ \\
\hline 9 & $\begin{array}{c}\text { Nossa Senhora da } \\
\text { Piedade }\end{array}$ & Chácara - MG - Brazil \\
\hline
\end{tabular}

\section{Near infrared}

Infrared analyses were performed in a Bruker Tensor 37, FT-NIR spectrometer (Bruker Optics, Ettlingen, Germany) equipped with an integrating sphere and operating in reflectance mode. There were 64 scans with resolution of 4 $\mathrm{cm}^{-1}$ and a spectral range of $4000-10000 \mathrm{~cm}^{-1}$. Spectra were obtained directly from all surfaces of samples, without identification of section in a number of 20 by object. Surface with paint was not applied in spectra acquisition.

Samples from Cedrela sp. (cedar) obtained in wood collection from Laboratory of Wood Anatomy and Quality, at Federal University of Parana, were applied as reference material to evaluate the potential of near infrared in species discrimination.

The species was much important in sacred art on century XVIII (COELHO, 2005). A total of 200 spectra were applied in data analysis, 180 from unknown material (9 sacred objects) and 20 from reference sample. All measurements were obtained in a room with temperature of $23 \pm 2^{\circ} \mathrm{C}$ and $60 \%$ of relative humidity.
The Unscrambler X chemometric program (version 10.1, CAMO Software, Oslo, Norway) was applied to analyze data. Exploratory modeling was done by analyzing the score and loading graphs obtained by principal component analysis (PCA), based on algorithm NIPALS with mean centered data and cross validation to verify possible differences between samples. Data were evaluated in raw form and after pretreatment by the first and second derivative of SavitzkyGolay (polynomial order $=2$, smoothing point $=21$ ). A cluster analysis was performed with better data in PCA distribution to confirm grouping results applying Hierarchical Average-Linkage method and correlation as distance.

\section{Results and Discussion}

\section{Near infrared}

Analysis was done with reference sample of Cedrela $s p$. and all spectra from sacred images to verify possible similarity of them or grouping formation. Mean original spectra of all material are similar (Figure 2A) and some differences was observed in spectra from São José de Botas in regions from $4160-4370 \mathrm{~cm}^{-1}$ and $4600-4815 \mathrm{~cm}^{-1}$ which is related in literature principally to cell wall content, cellulose, hemicelluloses and lignin (SCHWANNINGER et al., 2011). To eliminate some noise in functions of differences in baseline and sample characteristics, as degradation, residual of paint, insect damage, pretreatment of first (Figure 2B) and second derivative (Figure 2C) was evaluated. In both derivative cases, it was possible to observe that region from $4000-6000 \mathrm{~cm}^{-1}$ is more informative. Also, spectra from São José de Botas showed some irregularities after first derivative $\left(4720-4735 \mathrm{~cm}^{-1} ; 6023 \mathrm{~cm}^{-1}\right)$ and second derivative $(4236 \mathrm{~cm}$ ${ }^{1} ; 4650 \mathrm{~cm}^{-1}$ ) in bands related to cell wall content, which can be the result of anatomic characteristics. 


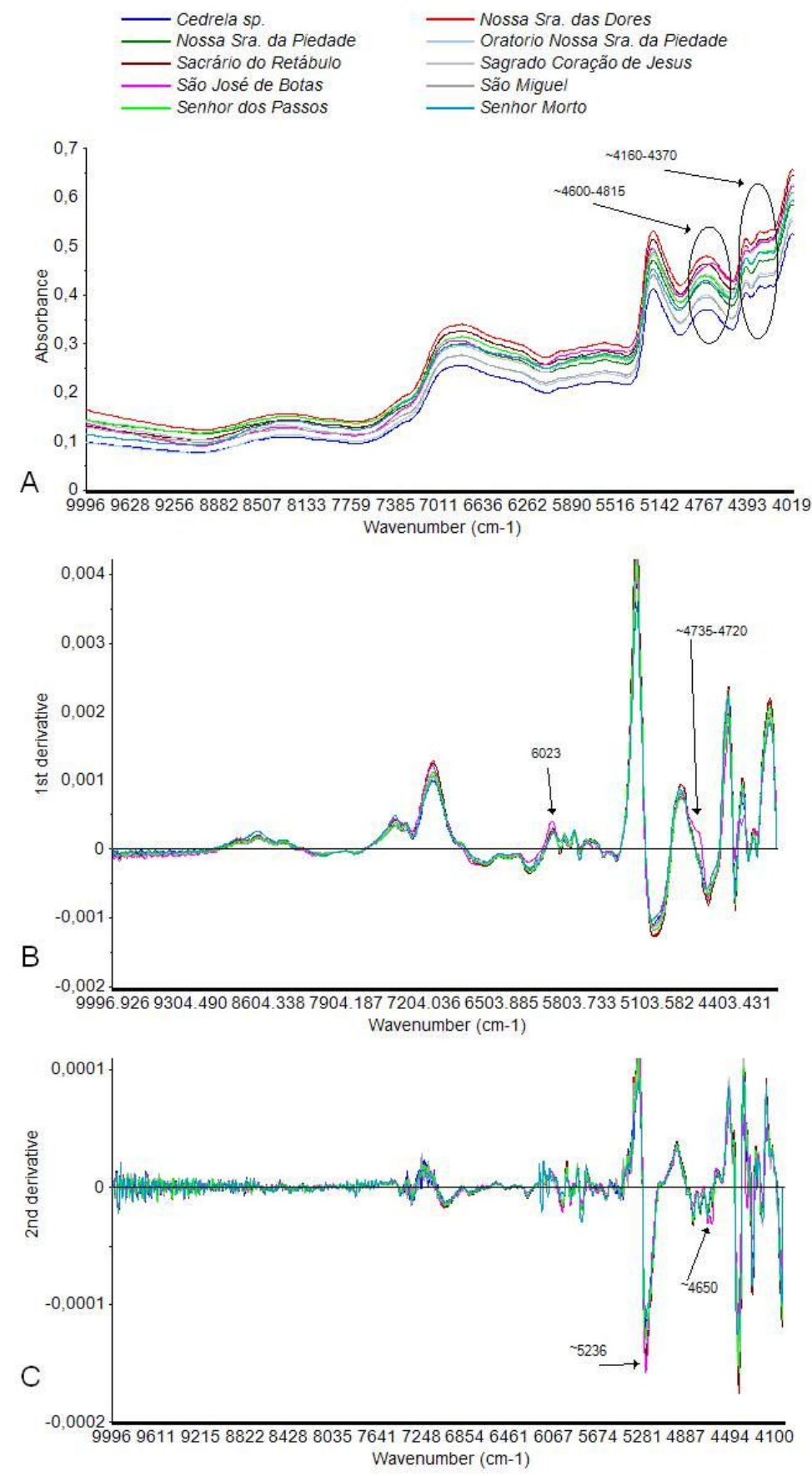

Figure 2. Mean NIR spectra of Cedrela sp. and nine sacred objects: (A) original spectra; (B) first derivative spectra; (C) second derivative spectra.

Figura 2. Espectro NIR médio de Cedrela sp. e nove objetos sacros: (A) espectro original; (B) espectro em primeira derivada; (C) espectro em segunda derivada.

Principal Component Analysis (PCA) was performed with original spectra, first and second derivative, with and without cedar samples. Results with and without the reference material were the same. Only best grouping result from second derivative is shown (Figure 3). Three principal components can explain $77 \%$ of material differences and three groups can be verified: i) samples from São José de
Botas, ii) samples from Cedrela sp., Sacrário do Retábulo, Oratório Nossa Senhora da Piedade, São Miguel, Nossa Senhora das Dores, Senhor dos Passos and Nossa Senhora da Piedade, called cedar group; iii) samples from Senhor Morto and Sagrado Coração de Jesus.

Also, a cluster analysis was done with the same data from Figure 3, second derivative NIR spectra in region 4000-6000 
$\mathrm{cm}^{-1}$, to confirm grouping formation and potential of near infrared in discrimination of cedar samples. Results are shown as dendrogram (Figure 4A) and PCA based on classified data after cluster analysis (Figure 4B).

Samples from different species present distinction in chemical composition of cell wall in function of fiber wall thickness and degradation. Material from Sagrado Coração de Jesus shows attack of insect with galleries or holes; and also, some degradation was verified because material is much fragile. Sample from Senhor Morto present little vessels and homogeneous texture and also is lighter than other materials.
Mean second derivative spectra of Cedrela sp. and material not grouped with cedar (Figure 5) shows some regions with more influence in its separation: bands at 5236 and $4283 \mathrm{~cm}^{-1}$ are related to hemicelluloses content; wavenumbers at 4808,4362 and $4019 \mathrm{~cm}^{-1}$ are attributed to cellulose; band at $4686 \mathrm{~cm}^{-1}$ is described as lignin and extractives and also acetyl groups in hemicelluloses; region between 4422-4401 is related to all cell wall components and band at $4195 \mathrm{~cm}^{-1}$ is assigned to lignin content (SCHWANNINGER et al., 2011).

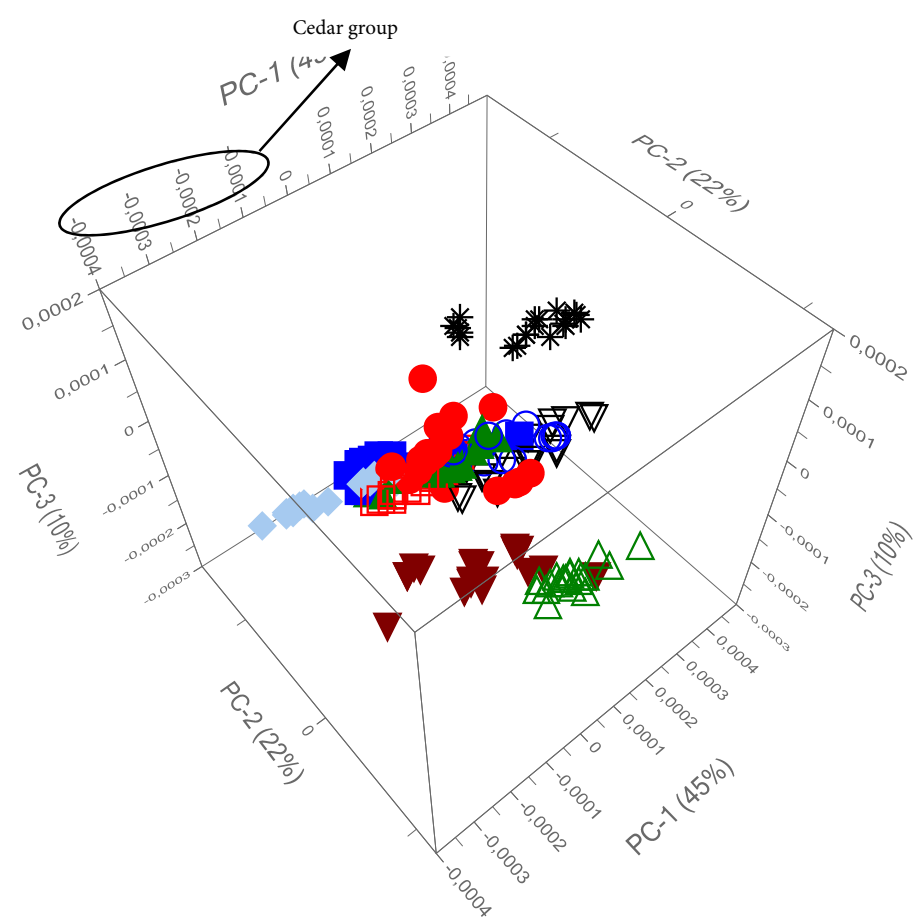

$\begin{array}{ll} & \text { NSra Dores } \\ & \text { NSra Piedade } \\ & \text { Oratorio NSra Piedade } \\ & \text { Sacrario } \\ \nabla & \text { Sgdo Coração } \\ * & \text { S Jose Botas } \\ \bigcirc & \text { S Miguel } \\ \square & \text { Sr Passos } \\ \triangle & \text { Sr Morto } \\ \nabla & \text { Cedrela sp. }\end{array}$

Figure 3. Score graphic from PCA with second derivative NIR spectra in region 4000-6000 $\mathrm{cm}^{-1}$ from nine sacred objects. Figura 3. Gráfico de scores do PCA com espectro NIR em segunda derivada na região 4000-6000 $\mathrm{cm}^{-1}$ de nove objetos sacros. 


\section{S. J. Botas}

\section{Sr. Morto}

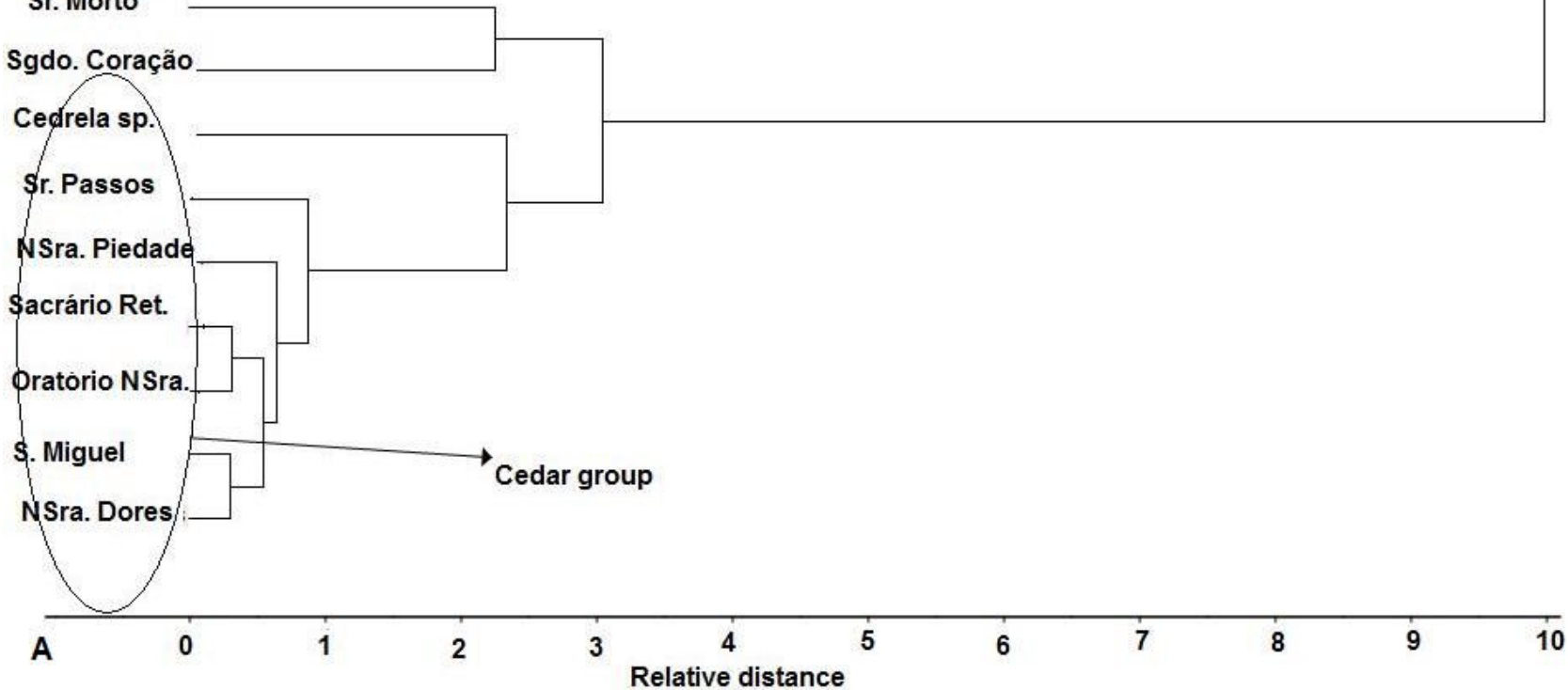

- Sgdo. Coração Jesus

- NSra.Dores, Piedade, Sacrário, S.Miguel, Sr. Passos

- Cedrelasp.

\section{Sr. Morto}

$\nabla$ S. José de Botas

B

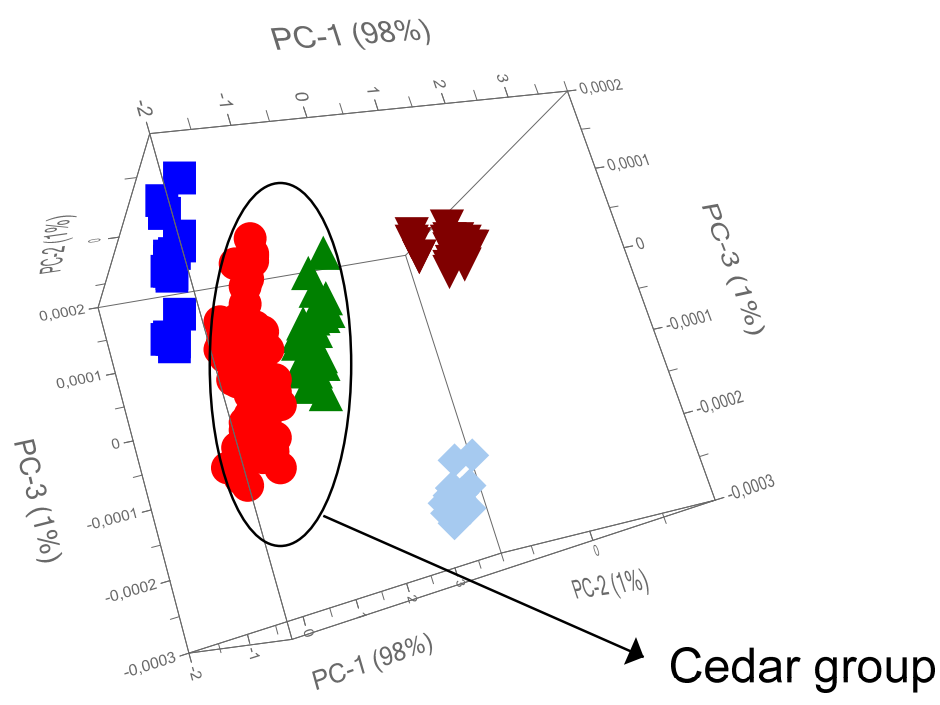

Figure 4. Results of cluster analysis based on second derivative NIR spectra in region $4000-6000 \mathrm{~cm}^{-1}$ from nine sacred objects. Dedrogram (A) and PCA score graphic (B)

Figura 4. Resultados da análise de cluster baseada na segunda derivada do espectro NIR na região de $4000-6000 \mathrm{~cm}^{-1}$ de nove objetos sacros. Dendrograma (A) e gráfico de scores do PCA (B). 


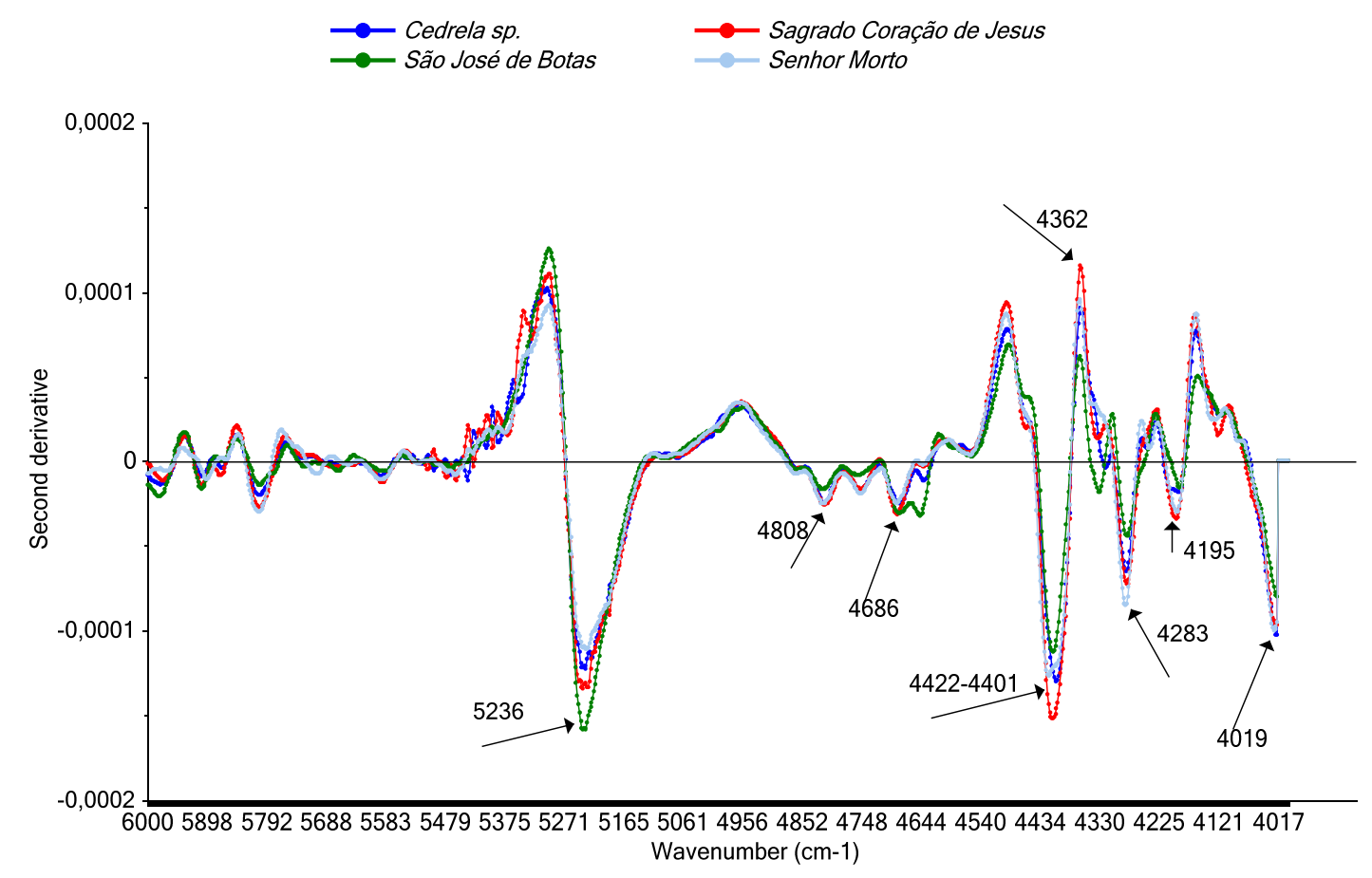

Figure 5. Mean NIR spectra with second derivative in region $4000-6000 \mathrm{~cm}^{-1}$ for species identified as no cedar group.

Figura 5. Espectro NIR médio com a segunda derivada na região $4000-6000 \mathrm{~cm}^{-1}$ para espécies identificadas como não pertencentes ao grupo cedro.

The efficient pretreatment with second derivative in wood discrimination was also reported in studies related to geographic provenance of timber (SANDAK et al., 2011), pine species (ZHANG et al., 2014; HORIKAWA et al., 2015; HWANG et al., 2016) and "angelim" Brazilian group (MUÑIZ et al., 2016).

Literature also shows the influence of species group in the division of spectral range to its discrimination. In species similar to mahogany, Pastore et al. (2011) verified that wavenumbers from 4249-6100 $\mathrm{cm}^{-1}$ were the most informative, and Bergo et al. (2016) identified 155 samples of Swietenia macrophylla King (Meliaceae) from 27 countries with a correct classification rate higher than $96.8 \%$ in region from 5547 to $6897 \mathrm{~cm}^{-1}$. Similar range, from $4000-6200 \mathrm{~cm}^{-1}$ presented adequate results in discriminating six provenances of Sugi in south Brazil (NISGOSKI et al., 2016) and 4000$5000 \mathrm{~cm}^{-1}$ plus $5500-6200 \mathrm{~cm}^{-1}$ resulted in separation of wood and charcoal from "Angelim" Brazilian group (MUÑIZ et al., 2016). Toscano et al. (2017) verified informative wavenumbers from $4000-7500 \mathrm{~cm}^{-1}$ in differentiation of bark and wood from pine, fir and beech, and also the separation of hardwood and softwood. On the other hand, Gierlinger et al. (2004) find spectral differences in second derivative NIR spectra of three larch species only in region from 6300-6700 $\mathrm{cm}^{-1}$ and Hwang et al. (2016) discussed the region between $4000-8000 \mathrm{~cm}^{-1}$ in identification of pinus species in Korean architecture.

\section{Wood Anatomy}

Material was recognized as four different genera (Table 2), illustrated in Figures 6-7 and described based on its identification. Most samples are from genus Cedrela, a much important and traditional wood in sacred art.

Samples 1-3, 5-6 and 9 (Figure 6) were identified as genus Cedrela (cedar): wood present growth ring boundaries distinct by parenchyma marginal and semi ring porous; solitary vessels and radial multiple from 2-3, with gums or 
other deposits, simple perforation plates, intervessel pits alternate. Fibers thin walled, non-septate. Axial parenchyma marginal, in bands with three or more cells wide; in some samples diffuse parenchyma was observed. Rays homogeneous and heterogeneous present, body ray cells procumbent with one row of square marginal cells, multiseriate of 2-3, not storied.

Sample 4 (Figure 7) - São José de Botas was identified as genus Entandrophragma (african mahogany): wood present growth rings boundaries indistinct or demarked by marginal parenchyma; diffuse porous, solitary vessel and radial multiple from 2-3 present, simple perforate plate, intervessel pits alternate. Fibres medium thickness, septate. Axial parenchyma in bands. Rays heterogeneous, multiseriate of 23, not storied.

Table 2. Samples identification based on anatomical characteristics.

Tabela 2. Identificação das amostras com base nas características anatômicas.

\begin{tabular}{|c|c|c|}
\hline Sacred Images & Genus & Family \\
\hline $\begin{array}{c}\text { 1- Sacrário do } \\
\text { Retábulo }\end{array}$ & $\begin{array}{l}\text { Cedrela P. } \\
\text { Browne }\end{array}$ & Meliaceae \\
\hline $\begin{array}{l}2 \text { - Oratório de Nossa } \\
\text { Senhora da Piedade }\end{array}$ & $\begin{array}{l}\text { Cedrela P. } \\
\text { Browne }\end{array}$ & Meliaceae \\
\hline 3 - São Miguel & $\begin{array}{l}\text { Cedrela P. } \\
\text { Browne }\end{array}$ & Meliaceae \\
\hline 4 - São José de Botas & $\begin{array}{c}\text { Entandrophragma } \\
\text { C. DC. }\end{array}$ & Meliaceae \\
\hline $\begin{array}{c}5 \text { - Nossa Senhora das } \\
\text { Dores }\end{array}$ & $\begin{array}{l}\text { Cedrela P. } \\
\text { Browne }\end{array}$ & Meliaceae \\
\hline 6 - Senhor do Passos & $\begin{array}{l}\text { Cedrela P. } \\
\text { Browne }\end{array}$ & Meliaceae \\
\hline 7 - Senhor Morto & $\begin{array}{l}\text { Plathymenia } \\
\text { Benth. }\end{array}$ & Fabaceae \\
\hline $\begin{array}{c}8 \text { - Sagrado Coração } \\
\text { de Jesus }\end{array}$ & Tilia L. & Malvaceae \\
\hline $\begin{array}{c}9 \text { - Nossa Senhora da } \\
\text { Piedade }\end{array}$ & $\begin{array}{l}\text { Cedrela P. } \\
\text { Browne }\end{array}$ & Meliaceae \\
\hline
\end{tabular}

Sample 7 - Senhor Morto (Figure 7) was identified as from genus Plathymenia (vinhatico): wood present growth rings boundaries identified by changes in fiber wall thickness; diffuse porous, solitary vessel and radial multiple from 2-3 present, simple perforate plate, intervessel pits alternate.
Fibers thin to thick-walled, septate present. Axial parenchyma scanty paratracheal, vasicentric and confluent present, sometimes aliform. Crystals present. Rays homogeneous with procumbent cells, uniseriate predominant, irregular storied.

Sample 8 - Sagrado Coração de Jesus (Figure 7) was identified as from genus Tilia (basswood): wood present growth rings boundaries distinct by marginal parenchyma; diffuse porous, solitary vessel, radial multiples 2-3 and cluster common, tyloses present, simple perforate plate, intervessel pits alternate, helical thickness throughout body of vessel element. Fiber thin to thick, no septate. Axial parenchyma in marginal bands, diffuse-in-aggregates. Ray homogeneous with all cells procumbent, ray width 1 to 3 cells, ray height $>$ $1 \mathrm{~mm}$, not storied.

To a better comparison, microscopic images of genera Cedrela (reference wood), Entandrophragma (São José de Botas), Plathymenia (Senhor Morto) and Tilia (Sagrado Coração de Jesus) were obtained (Figure 8) and can justify spectra distribution in near infrared analysis.

\section{NIR $\mathrm{x}$ wood anatomy identification}

Based on NIR analysis, six sacred objects are much similar to cedar and can be from genera Cedrela, other three may be from different genera. Image from São José de Botas was similar, samples in PCA are out of cedar group, and based on anatomic characteristics was identified as the same family, but another botanical genus (Entandrophragma). Wood in the same botanic family of cedar (Cedrela), i.e. from Meliaceae family, includes genera Carapa Aubl., Entandrophragma C. DC., Guarea F. Allan ex L., Khaya A. Juss and Swietenia Jacq. As related by Pastore et al. (2011) and Bergo et al. (2016) NIR infrared is efficient in discriminations of these woods.

Near infrared results showed the grouping of species identified by wood anatomic characteristics as from genus Cedrela sp. and separated from genera Entandrophragma, Plathymenia and Tilia. 
Samples were small, with painting and material from Sagrado Coração de Jesus showed xylophages attack. Even with these characteristics, NIR infrared showed potential to species discrimination in sacred art and can be applied as an auxiliary tool to wood anatomy in wooden objects to facilitate wood identification and restoration.
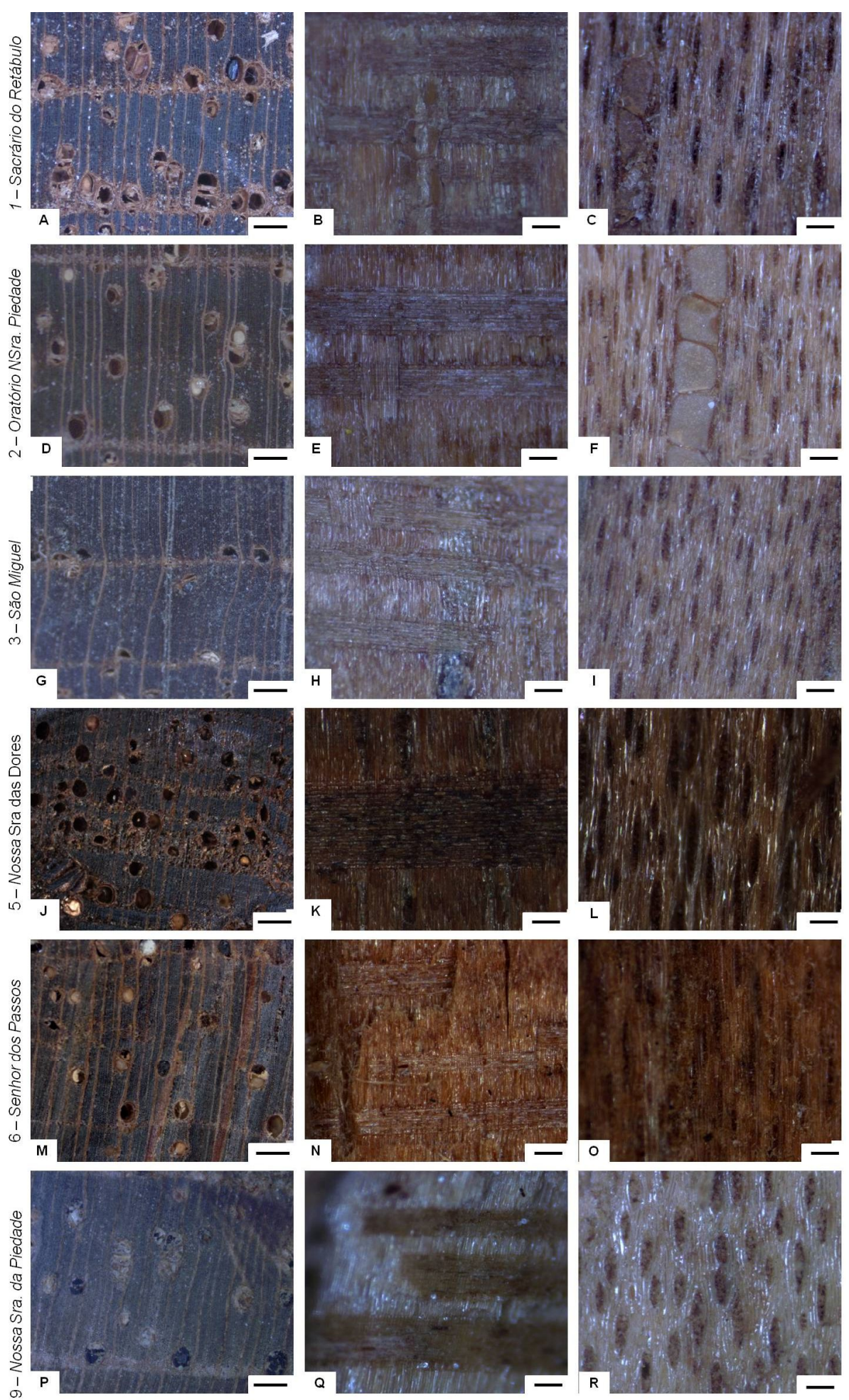

Figure 6. Macroscopic images from sacred objects identified as genus Cedrela. Transversal (A,D,G,J,M,P, Scale bar $=500 \mu \mathrm{m})$, radial $(\mathrm{B}, \mathrm{E}, \mathrm{H}, \mathrm{K}, \mathrm{N}, \mathrm{Q}$, Scale bar $=200 \mu \mathrm{m})$ and tangential $(\mathrm{C}, \mathrm{F}, \mathrm{I}, \mathrm{L}, \mathrm{O}, \mathrm{R}$, Scale bar $=200 \mu \mathrm{m})$ sections.

Figura 6. Imagens macroscópicas dos objetos sacros identificados como gênero Cedrela. Seção transversal (A, D, G, J, M, P, barra $=500 \mu \mathrm{m}), \operatorname{radial}(\mathrm{B}, \mathrm{E}, \mathrm{H}, \mathrm{K}, \mathrm{N}, \mathrm{Q}$, barra $=200 \mu \mathrm{m})$ e tangencial $(\mathrm{C}, \mathrm{F}, \mathrm{I}, \mathrm{L}, \mathrm{O}, \mathrm{R}$, barra $=200 \mu \mathrm{m})$. 

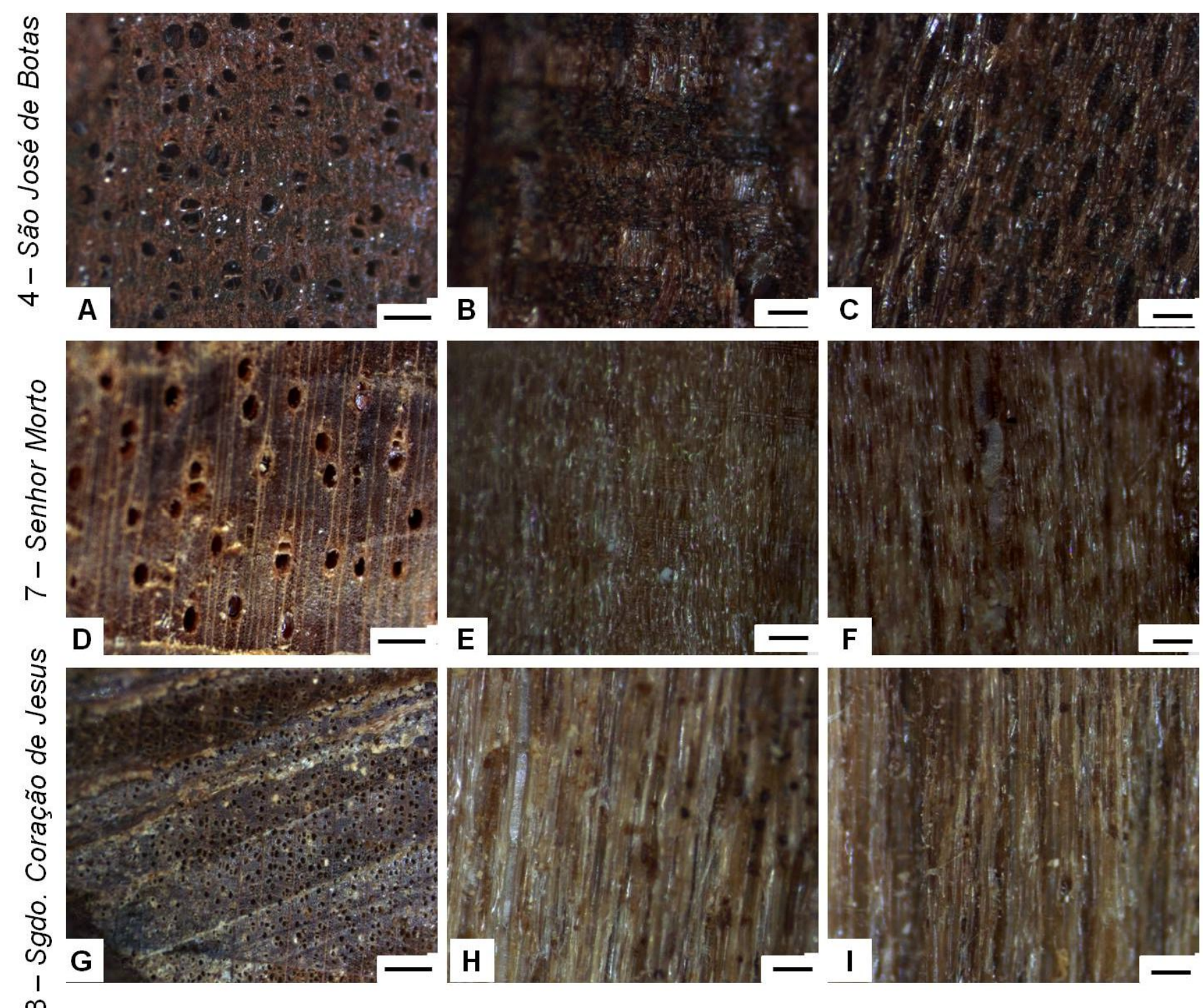

Figure 7. Macroscopic images from sacred objects identified as genus Entandrophragma (A, B, C), Plathymenia (D, E, F) and Tilia (G, H, I). Transversal (A, D, G, Scale bar $=500 \mu \mathrm{m})$, radial (B, E, H, Scale bar $=200 \mu \mathrm{m})$ and tangential $(\mathrm{C}, \mathrm{F}, \mathrm{I}, \mathrm{Scale}$ bar $=200 \mu \mathrm{m})$ sections.

Figura 7. Imagens macroscópicas dos objetos sacros identificados como gênero Entandrophragma (A, B, C), Plathymenia (D, E, F) e Tilia $(G, H, I)$. Seção transversal $(A, D, G$, barra $=500 \mu \mathrm{m})$, radial $(B, E, H$, barra $=200 \mu \mathrm{m})$ e tangencial $(C, F, I$, barra $=$ $200 \mu \mathrm{m})$. 

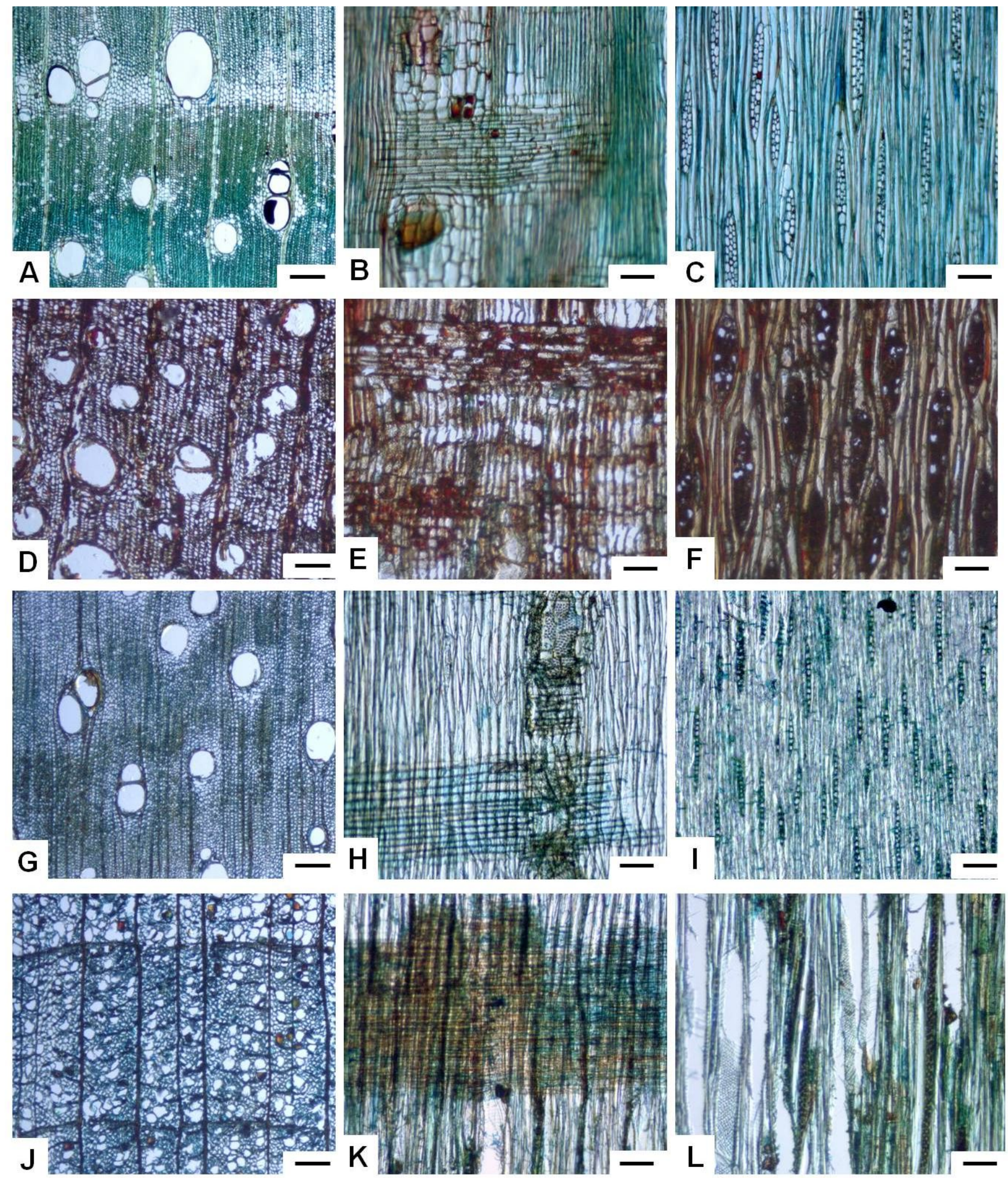

Figure 8. Microscopic images of Cedrela sp. (A, B, C), Entandrophragma sp. (D,E,F), Plathymenia sp. (G, H, I) and Tilia sp. (J, K, L). Transversal (A, D, G, J, Scale bar $=200 \mu \mathrm{m})$, radial $(B, E, H, K$, Scale bar $=100 \mu \mathrm{m})$ and tangential $(C, F, I, L$, Scale bar $=$ $100 \mu \mathrm{m})$ sections.

Figura 8. Imagens microscópicas de Cedrela sp. (A, B, C), Entandrophragma sp. (D, E, F), Plathymenia sp. (G, H, I) e Tilia sp. (J, K, L). Seção transversal (A, D, G, J, barra $=200 \mu \mathrm{m})$, radial $(B, E, H, K$, barra $=100 \mu \mathrm{m})$ e tangencial $(\mathrm{C}, \mathrm{F}, \mathrm{I}, \mathrm{L}$, barra $=100$ $\mu \mathrm{m})$. 


\section{Conclusions}

Six samples from sacred objects were from Cedrela sp., three others were each one from genera Entandrophragma, Plathymenia and Tilia. Principal differences in anatomic characteristics were observed in distinction of growth rings, porosity and axial parenchyma.

Near infrared grouped material with similar characteristics to Cedrela sp. and showed the potential to be applied as an auxiliary tool to anatomical characterization in wood sacred images identification. Bands related to cell wall composition were most important in material discrimination, and some region related to extractives also can be evaluated.

\section{Acknowledgements}

Authors thanks to Atelier de Conservação e Restauração de Bens Culturais - Juiz de Fora, Minas Gerais, Brazil for supplying material and CNPq Brazil (PQ 303374/2016-0).

\section{References}

ANDREACCI, F.; MELO JÚNIOR, J.C.F. Madeiras históricas do barroco mineiro: interfaces entre o patrimônio cultural material e a anatomia da madeira. Rodriguésia, v.62, n.2, p.241-251, 2011.

BERGO, M.C.J.; PASTORE, T.C.M.; CORADIN, V.T.R.; WIEDENHOEFT, A.C.; BRAGA, J.W.B. NIRS identification of Swietenia macrophylla is robust across specimens from 27 countries. IAWA Journal, v.37, n.3, p.420-430, 2016.

BUOSO, M.C.; DE POLI, M.; MATTHAES, P.; SILVESTRIN, L.; ZAFIROPOULOS, D. Nondestructive wood discrimination: FTIR - Fourier Transform Infrared Spectroscopy in the characterization of different wood species used for artistic objects. Applications of Nuclear Techniques (CRETE15) International Journal of Modern Physics, Conference Series v.44, p.1660212, 2016.

CLOUTIS, E.; MACKAY, A.; NORMAN, L.; GOLTZ, D. Identification of historic artists' pigments using spectral reflectance and X-ray diffraction properties I. Iron oxide and oxy-hydroxide-rich pigments. Journal of Near Infrared Spectroscopy, v.24, p.27-45, 2016 a.
CLOUTIS, E.; NORMAN, L.; CUDDY, M.; MANN, P. Spectral reflectance $(350-2500 \mathrm{~nm})$ properties of historic artists' pigments. II. Red-orange-yellow chromates, jarosites, organics, lead(-tin) oxides, sulphides, nitrites and antimonates. Journal of Near Infrared Spectroscopy, v.24, p.119-140, 2016b.

COELHO, B. Devoção e Arte: Imaginária religiosa em Minas Gerais. Edusp: São Paulo, 2005. pp233-245.

DOWNES, G.M.; DREW, D.M. Climate and growth influences on wood formation and utilization. Southern Forests, v.70, n.2, p.155-167, 2008.

GASSON, P. How precise can wood identification be? Wood Anatomy's role in support of the legal timber trade, especially CITES. IAWA Journal, v.32, n.2, p.137-154, 2011.

GIERLINGER, N.; SCHWANNINGER, M.; WIMMER, R. Characteristics and classification of Fourier-transform near infrared spectra of the heartwood of different larch species (Larix sp.) Journal of Near Infrared Spectroscopy, v.12, p.113-119, 2004.

HOBRO, A.J.; KULIGOWSKI, J.; DÖLL, M.; LENDL, B. Differentiation of walnut wood species and steam treatment using ATR-FTIR and partial least squares discriminant analysis (PLS-DA). Analytical and Bioanalytical Chemistry, v.398, p.2713-2722, 2010.

HORIKAWA, Y.; TAZURU, S.M.; SUGIYAMA, J. Nearinfrared spectroscopy as a potential method for identification of anatomically similar Japanese diploxylons. Journal of Wood Science, v.61, p.251-261, 2015.

HWANG, S.W.; HORIKAWA, W.H.; LEE, W.H.; SUGIYAMA, J. Identification of Pinus species related to historic architecture in Korea using NIR chemometric approaches. Journal of Wood Science, v.62, p.156-167, 2016.

IAWA. List of microscopic features for hardwood identification. IAWA Bulletin, v.10, n.3, p.219-332, 1989.

INAGAKI, T.; MITSUI, K.; TSUCHIKAWA, S. Nearinfrared spectroscopic investigation of the hydrothermal degradation mechanism of wood as an analogue of archaeological wood. Part II: Hardwood. Applied Spectroscopy, v.63, n.7, p.753-758, 2009.

LARGO-GOSENS, A.; HERÁNDEZ-ALTAMIRANO, M.; GARCÍA-CALVO, L.; ALONSO-SIMÓN, A.; ÁLVAREZ, J.; ACEBES, J.L. Fourier transform mid infrared spectroscopy applications for monitoring the structural plasticity of plant 
cell walls. Frontiers in Plant Science: Plant Biophysics and Modeling, v.5, article 303, 2014.

LAZARESCU, C.; HART, F.; PIROUZ, Z.; PANAGIOTIDIS, K.; MANSFIELD, S.D.; BARRETT, J.D.; AVRAMIDIS, S. Wood species identification by near-infrared spectroscopy. International Wood Products Journal, v.8, n.1, p.32-35, 2017.

LUCEJKO, J.J.; MODUGNO, F.; RIBECHINI, E.; TAMBURINI, D.; COLOMBINI, M.P. Analytical instrumental techniques to study archaeological wood degradation. Applied Spectroscopy Reviews, v.50, n.7, p.584-625, 2015.

MELO JÚNIOR, J.C.F. Anatomia de madeiras históricas: um olhar biológico sobre o patrimônio cultural. Joinville, SC: Editora Univille, 2012. 132p.

MUÑIZ, G.I.B.; CARNEIRO, M.E.; BATISTA, F.R.R.; SCHARDOSIN, F.Z; NISGOSKI, S. Wood and charcoal identification of five species from the miscellaneous group known in Brazil as "angelim" by near-ir and wood anatomy. Maderas. Ciencia y tecnología, v.18, n.3, p.505 - 522, 2016.

NISGOSKI, S.; SCHARDOSIN, F.Z.; BATISTA, F.R.R.; MUÑIZ, G.I.B.; CARNEIRO, M.E. Potential use of NIR spectroscopy to identify Cryptomeria japonica varieties from southern Brazil. Wood Science and Technology, v.50, n.1, p.71-80, 2016.

NISGOSKI, S.; MUÑIZ, G.I.B.; GONÇALVES, T.A.P.; BALLARIN, A.W. Use of visible and near-infrared spectroscopy for discrimination of eucalypt species by examination of solid samples. Journal of Tropical Forest Science, v.29, p.371-37, 2017.

PASTORE, T.C.M.; BRAGA, J.W.B.; CORADIN, V.T.R.; MAGALHÃES, W.L.E.; OKINO, E.Y.A.; CAMARGOS, J.A.A.; DE MUNIZ, G.I.B.; BRESSAN, O.A.; DAVRIEUX, F. Near infrared spectroscopy (NIRS) as a potential tool for monitoring trade of similar woods: discrimination of true magogany, cedar, andiroba and curupixá. Holzforschung, v.65, n.1, p.73-80, 2011.

ROMAGNOLI, M.; SARLATTO, M.; TERRANOVA, F.; BIZZARRI, E.; CESETTI, S. Wood identification in the Cappella Palatina Ceiling ( $12^{\text {th }}$ century) in Palermo (Sicily, Italy). IAWA Journal, v.28, n.2, p.109-123, 2007.

SANDAK, A.; SANDAK, J.; PRĄDZYŃSKI, W.; ZBOROWSKA, M.; NEGRI, M. Near infrared spectroscopy as a tool for characterization of wood surface. Folia Forestalia Polonica. Series B, Issue 40, 31-40, 2009.
SANDAK, A.; SANDAK, J.; ZBOROWSKA, M.; PRADZYNSKI, W. Near infrared spectroscopy as a tool for archaeological wood characterization. Journal of Archaeological Science, v.37, p.2093-2101, 2010.

SANDAK, A.; SANDAK, J.; NEGRI, M. Relationship between near-infrared (NIR) spectra and geographic provenance of timber. Wood Science and Technology, v.45, n.1, p.35-48, 2011.

SCHWANNINGER, M.; RODRIGUES, J.C.; FACKLER, K. A review of band assignments in near infrared spectra of wood and wood components. Journal of Near Infrared Spectroscopy, v.19, p.287-308, 2011.

SOARES, L.F.; DA SILVA, D.C.; BERGO, M.C.J.; CORADIN, V.T.R.; BRAGA, J.W.B.; PASTORE, T.C.M. Avaliação de espectrômetro NIR portátil e PLS-DA para a discriminação de seis espécies similares de madeiras amazônicas. Quimica Nova, v.40, n.4, p.418-426, 2017.

TOSCANO, G.; RINNAN, A.; PIZZI, A.; MANCINI, M. The use of near-infrared (NIR) spectroscopy and principal component analysis (PCA) to discriminate bark and wood of the most common species of the pellet sector. Energy Fuels, v.31, p.2814-2821, 2017.

TRAORÉ, M.; KAAL, J.; CORTIZAS, A.M. Application of FTIR spectroscopy to the characterization of archeological wood. Spectrochimica Acta Part A: Molecular and Biomolecular Spectroscopy, v.153, p.63-70, 2016.

TSUCHIKAWA, S.; KOBORI, H. A review of recent application of near infrared spectroscopy to wood science and technology. Journal of Wood Science, v.61, p.:213-220, 2015.

ZHANG, X.; YU, H.; LI, B.; LI, W.J.; LI, X.; BAO, C. Discrimination of Pinus yunnanensis, $P$. kesiya and $P$. densata by FT-NIR. Journal of Chemical and Pharmaceutical Research, v.6, n.4, p.142-149, 2014. 